\title{
EVALUATION OF QUALITY ASSURANCE PROGRAM
}

\author{
Murni Yanto \\ State Islamic High School Bengkulu \\ murni_yanto79@yahoo.com
}

This study is to investigate the implementation of the evaluation program of quality assurance State Islamic High School Curup. This study design is evaluative survey. In this study, the level of implementation of the evaluation results are divided into five categories, namely: excellent, good, average, less, much less. The results of the evaluation study the implementation of quality assurance programs included in both categories. Program quality assurance Sekolah Tinggi Agama Islam Negeri Curup necessary to repair all fronts, this can be illustrated as follows: (1) Basic policy program quality assurance, (2) resource program quality assurance, (3) implementation of the guarantee program, (4) Results the achievement of a quality assurance program. The results of the study suggested the central quality assurance to be able to follow up on some of the findings, especially concerning the quality assurance program resources, training and dissemination of quality, and implement improved quality assurance program so that the process of quality assurance programs to be more effective.

\section{Keywords : Evaluation, Implementation of the quality program, CIPP}

Improving the quality of Indonesian human life through education becomes a strategic issue for Indonesian human resources. Therefore, the implementation of education for the state becomes an absolute to achieve the ideals of educating the life of a nation with social justice. Efforts to educate the nation's life are done in various ways such as the improvement and internalization of the values of knowledge, education, work and religious. In the world of Islamic education in Indonesia, the development of quality of life acquires Islamic knowledge systematically and intensely implemented in Islamic Higher Education.Quality is a dynamic condition associated with products, services, processes, and environments that meet or exceed expectations and help generate more value.

As a higher education STAIN Curup has a quality assurance program, firstly, the quality of the quality assurance program. Second, the support program over the status of STAIN to IAIN.Third, socialization of quality assurance. Fourth, lecturer scholarship program. Fifth, Development of quality assurance book. Sixth, preparation of self-evaluation book.

Rinda Hedwig (2006: 1) In the environment of higher education quality assurance is the services provided by universities to stakeholders, consisting of students, alumni, graduate / industrial users, and parents of students. The position and importance of quality assurance at universities high it can be argued that in the future, the existence of universities is not solely dependent on the government, but mainly depends on the stakeholder assessment, ie students, parents, the world of work, government, lecturers, support staff, and other interested parties , about the quality of college. Students, alumni, graduate users, and student parents are satisfied if the college can provide assurance that the college can provide the best according to the customer.

The theory of program evaluation is explained by Blaine R Worthen, Jamer R A man who has done something, will surely judge whether what he does has been in accordance with his procedures and desires, (1987: 4). According to Worthen and Sanders the evaluation is looking for something worth (1987: 4), while Joan L Herman states everything that someone is trying to do in the hope of bringing about results or influence (1995: 9), Egon G. Gube and Yvonna S. Lincoin evaluation models such as: Countenance model, Context-Input-Process-Produt model, goal-free model, and Connoisseurship model (1981: 11-18), according to Donald L Kirkpatrik's and James D, Kirkpatrik'sada four levels are: (1) reaction, (2) learning, (3) behaviour, (4) result (2000: 21), Daniel L Stufflebeam, George F. Madaus, and Thomas Kallaghan proposed this model is designed to 
promote growth (2000: 283).

It is difficult to give an evaluation opinion is a process that determines the conditions, where a goal can be achieved (2008: 4), according to Suharsimi Arikunto and Cepi Safruddin Abdul Jabar evaluation is Activities to collect information about the work of something, which then the information is used to determine alternatives (2004: 1), Wirawan believes that evaluation is a result of an assessment of the impact that occurred after the program was implemented (2008: 15-16), according to S. Puto Widoyoko, the usefulness of the evaluation proposed, namely: (a) communicating the program to the public, (b) provide information, (c) refine existing programs, and (d) increase participation. (2010: 11), Suharsimi Arikunto (2011: 92). a process of determining the outcomes that some activities have accomplished to support the achievement of program objectives.

The quality assurance theory described by Edwar Sallism suggests quality is something that satisfies and exceeds the wants and needs of the customer (2008: 58), while SthepenP.Robbins and mary Coulter suggests; "Quality is the abilities of a product or serviceto raliability do what it's supposed to do and to satisfy customer expectations" (2007: 607), according to Vincent Gasverz, quality is all the activity of the overall management function that determines the quality policy, goals and responsibilities answer and implement them through quality management tools, and quality improvement (2001: 122), David L. Goetsch, Stanley B. Davies explains "quality is a dynamic state associated with product services, people, processes, and environments that meets exceed expectations and help produce superior valuae.

Engkoswara, Aan Komariah argues that quality is the appropriate state and exceeds customer expectations so that customers get satisfaction (2010: 305), while Veithzal Rivai, Sylviana Pure "2010: 711), according to Rinda Hedwigpenjaminan quality is services provided by universities to stakeholders, consisting of students, alumni, graduate / industrial users, and parents of students (2006: 1), while Yoyon Bahtiar Irianto stated that the quality assurance is done by quality assurance program as an effort to implement as expected in order to meet customer satisfaction (2011: 34).

The main purpose of this research is to know and get a clear picture about the basic policy of Quality Assurance Program (Context), Quality Assurance Program (Input), Implementation of Quality Assurance Program (Process, and Program Outcome).

\section{METHOD}

The evaluation research focuses on assessing the effectiveness of a particular program or action in solving a particular problem. Therefore, the research method used is evaluative survey method. This evaluative survey activity is the main method of doing research.Fathoni stated in general the research method is different from the three main methods of case studies, experiments, and surveys. Furthermore, the evaluative survey method is surveying to evaluate a program, whether conducted on the implementation of an ongoing program (formative evaluation) and evaluation implemented at the end of a summative evaluation program Evaluation used is formative evaluation. Formative evaluation aims to improve the program. While summative evaluation is done to make a decision base on whether the program is effective and whether it should proceed.

\section{RESULT}

Data analysis technique in this research is quantitative and qualitative data analysis. Quantitative analysis is used as the basis for the preparation or mapping of components in evaluation, selanjutya in depth with qualitative analysis. Quantitative data analysis is with descriptive statistics. Analysis of qualitative data by means during analysis during data collection and analysis after data collected.

These data collection analyzes include: developing field notes, categorizing data, entering data into analytics format, and developing questions to collect further data. The analysis after the data collected includes collecting and arranging chronologically according to the time of data 
collection, re-encompassing the data and grouping it in one appropriate category and classification format, exposing the data after being analyzed in accordance with the component being evaluated, and drawing some conclusions. Detailed in accordance with sub focus of research then it can be concluded as follows: (1) The basis of policy of guarantee program of mutuhasil evaluation stated that result of evaluation for basic policy of quality assurance program got value equal to 82,5. The scores are in good category. Therefore, it can be stated that the program of quality assurance policy is very important. (2) the quality of the quality assurance program is in good category. For facilities and infrastructures are 64.4 (enough), 67,5 (enough), 66.2 (enough), and 75,5 (75.5) curriculum ), The student's program was 79.1, good category, the academic program was obtained by 71,5 good category. if calculated the average value of all aspects of the implementation of program resources, then the average value obtained by 71 acquisition of the average value can be stated that the implementation of program resources that get good value. (3) The implementation of quality assurance program is divided into: (a) Preparation of status STAIN (c) lecturer's education scholarship, d) development of quality assurance books, (e) preparation of self-evaluation books, and (4) The results of the category quality assurance program are divided into three aspects: (1) quality of program of quality assurance, (2) aspects of the program transfer status of STAIN to IAIN, and (3) aspects of lecturer education scholarship program.

\section{DISCUSSION}

Discussion of the results of the implementation evaluation stated here is a comparison between the findings with the evaluation criteria are done and set. As we know in this research there are four components that are evaluated are: Basic policy of quality assurance program (context), Quality Assurance Resources, Student Program (input) implementation of quality assurance program (Process), and program achievement result of quality assurance program (product), therefore the discussion of the findings refers to these components. Furthermore, the discussion discusses the findings of each component.

1. The quality of the quality assurance program that includes: Academic Quality Assurance Program, Curriculum, Teachers, Administrative Staff, Facilities and Facilities, student affairs are obtained by the average score of 71 good categories.

2. Implementation of Quality Assurance Program. Evaluation of the implementation of this program covers the aspects of: preparation of the support capacity to change status of STAIN to IAIN, quality assurance socialization program, lecturer scholarship program, development of quality assurance book, self evaluation book compilation, got value equal to 73,5 good category.

3. Result of Quality Assurance Program Implementation: Evaluation to program result addressed to three aspects: 1) quality of program of quality assurance, 2) support program of transfer status of STAIN to IAIN, 3) lecturer education scholarship program.

Quality assurance program resources: Implementation evaluation results for the program's program resources achieved an average score of 71 . In the evaluation criteria of implementation, the value is within a good category range. The acquisition of the value means that the implementation of STAIN's quality assurance program resources is in good condition. Of the four aspects of program resources evaluated.

Acquisition of value for the outcome of this program is consistent with the value of training and socialization. Therefore, the aspects that promote the value of the evaluation results for the implementation of the program are: (a) Implementation of lecturer quality control training and administration. Evaluation result on training aspect of quality control of lecturers and administration staff to get good result. It can be observed on the acquisition of evaluation result value for the implementation aspect of lecturer quality control training and administration. Acquisition of 77, good category. Obtaining the value indicates that the implementation of quality control training of lecturers and administrative staff is good. b) Socialization of laboratory quality assurance and 
socialization of curriculum based on KKNI. Evaluation result on socialization aspect of laboratory quality assurance was obtained 75, good category. While for the socialization aspect of curriculum based on KKNI get value equal to 70,5, good category, socialization of laboratory in university is very needed, hence need to see that still important with condition until now. (b) The support program over the status of STAIN to IAIN. The result of evaluation on the power aspect to support the transfer status of STAIN to IAIN in obtaining 75 (good) score has been maximized, by forming work committee and work in accordance with their respective function. From several committees in charge to request support from neighboring districts and provinces such as Lebong district, central Bengkulu district, South Bengkulu district, north Bengkulu district, Kaur regency, Seluma district, Bengkulu governor, Musi Rawas district, Muratara district, district parliament, Bengkulu Province, and Rejang Lebong district. All the support was put together, then presented at the Ministry of Religious Affairs of the Republic of Indonesia, attended by competent officials, in the hope that it could be realized because STAIN Curup was more than 40 years old, while IAIN Bengkulu has not reached 40 years has become IAIN. (c) Lecturer education scholarship program. Evaluation result on lecturer scholarship implementation aspect is obtained by 66,25 (Sufficient), pancasarjana education is one of education program at higher education which is designed to produce high competence human resources, , and able to access the latest information. Graduate education is expected to contribute substantially to various issues of higher education equity, relevance, quality, character development, competitiveness, and internationalization

\section{CONCLUSION}

Thus it can be concluded that the quality assurance program requires large resources and huge funding sources, so program evaluation is necessary to know how effective the implementation of quality assurance program is. First, the basic policy of quality assurance program. Given the importance of having a legal basis for the implementation of the program namelyUndang RI Number 20 of 2003 on National Education System, Government Regulation No. 30 of 1990 on Higher Education, PP. 19 of 2005 on National Education Standards, PP. No. 17 Year 2010 on the Management and Implementation of Education. Decree of the Minister of Religious Affairs No. 175 of 2008 on STATUTA STAIN Curupdan Decree of the Minister of Religious Affairs of the Republic of Indonesia concerning Statute of STAIN Curup in Bengkulu. Second, Evaluation of good quality category guarantee program resources are (a) academic guidance, (b) curriculum, (c) teaching staff, (d) administrative staff, (e) facilities and infrastructure, (f) student affairs. Thirdly, the implementation of Quality Assurance Program is: Supporting program of transferring status of STAIN to IAIN, quality assurance socialization program, lecturer education scholarship program, quality assurance development program, self-evaluation book program.

\section{REFERENCES}

Anna \& Fandi, Total Quality Management, Yogyakarta:Andi, 2001

Arikunto, Suharsimi, Dasar-dasar Evaluasi Pendidikan, Jakarta: PT.Bumi Aksara, 2001

Arikunto, Suharsimi dan Cepi Syafrudin Abdul Jabar. Evaluasi Program PendidikanPedoman Teoritis Praktis Bagi Mahasiswa dan Praktisi Pendidikan. Jakarta: PT. Bumi Aksara, 2004.

Arikunto, Suharsimi, Dasar-Dasar Evaluasi Pendidikan, Jakarta: PT. Bumi Aksara, 2011

A.Hanif Saha Gafur, Manajemen Penjaminan Mutu Perguruan Tinggi di Indonesia Jakarta: Bumi Aksara, 2008

Azwar Saifuddin, Penyusunan Skala Psikologi, Yogyakarta: Pustaka Pelajar,2013

Azwar Saifuddin, Dasar-Dasar Psikometri, Yogyakarta:Pustaka Pelajar,2005 
Bryman Alan, Social Research Methods, New York: Oxford University Press, 2004

Brinkerhoff, Robert O. Program Evaluation: A Practitionner's Guide for trainer and educators. Minnsota: Kluwer, 1983

Creswell, Jhon W ,Research design: Qualitative, Quantitative, and Mixed Method Aproaches,terjemahanAchmad Fawaid, Yogyakarta: Pustaka Pelajar, 2010

Daryanto, Evaluasi Pendidikan, Jakarta, Rineka Cipta, 2012

David L Goetsch,Stanley B. Davies, Quality Management For Organizational Excellence, New Jersey: Pearson Pretince Hall, 2010

Dali S, Naga, Pengantar Teori Sekor Pada Pengukuran Pendidikan, Jakarta: Gunadarma,1992

Djaali dan Pudji Muljono, Pengukuran Dalam Bidang Pendidikan,Jakarta: Gramedia Widiasarana Indonesia, 2008.

Gaspersz, vincent. ISO 9001:2000 and continual quality improvement. Jakarta: Gramedia Pustaka Utama, 2000.

Grabe Sven, Evaluation Manual, Paris: Unesco, 1993

Engkoswara. Aan Komariah. Administrasi Pendidikan,Bandung: Alfabeta, 2010

Hadi Anwar, Sistem Manajemen Mutu Laboratorium, Jakarta: Gramedia, 2000

Hanafiah, Nanang dan cucu suhana.konsep strategi pembelajaran. Bandung: Refika Aditama, 2009.

Hedwig, Rinda., Gerardus Polla. Model Sistem Penjaminan Mutu dan Proses Penerapannya di Perguruan Tinggi. Yogyakarta: Graha Ilmu, 2006

Herman, L Joan, How to Measure Performance and Use test, Los Angelas: Univrsity of California, 1995

John Daniel Globalization And Higher Education: Automobiles, Bananas, Courses, Degrees .(Proceedings) Paris (UNESCO).2002

Mahmud Marzuki, Manajemen Mutu Perguruan Tinggi, Jakarta: Raja Grafindo Persada, 2012

Margono,S,Metode Penelitian Pendidikan,Jakarta:Rineka Cipta,2010

Milddlehurst, Robin,Quality Assurance Implication of New Forms of Higher Education Helenki:2001

Moleong,LexyJ.Metodologi Penelitian Kualitatif, Bandung: Remaja, Rosdakarya, 2010.

Nasution. M. N. Manajemen Mutu Terpadu Total Quality Management, Jakarta: Ghalia, 2005

Rivai, Veithzal., Syilviana Murni. Education Management. Jakarta: Rajawali Pers, 2009

Rusman. Management kurikulum. Jakarta: Raja prasindo persada, 2008.

Sagala, Syaiful, Manajemen Berbasis Sekolah dan Masyarakat, Strategi Memenangkan Persaingan Mutu, Jakarta: Nimas Multima, 2006. 
Saha Gafur A. Hanif, Manajemen Penjaminan Mutu Perguruan Tinggi di Indonesia Jakarta, Bumi Aksara, 2008

Sallis, Edward. Total Quality Management in Education. London: KoganPage Limited,1993

Sanjaya, Wina, Strategi Pembelajaran Berorientasi Standar Proses Pendidikan, Jakarta:Kencana Prenada,2006

Stufflebeam Daniel L dan Antoni J, Shinkfield, Evaluasi Teori,Models, \& Aplication, San Pranc:John Wiley \& Son Inc, 2007

Sudjana, Nana. Penilaian Hasil Proses Belajar Mengajar, Bandung: PT.Remaja Rosdakarya, 2009

Sudijono Anas, Pengantar Evaluasi Pendidikan,Jakarta: Raja Grafindo Persada, 2013

Sudrajat dan M. Subana, Dasar—dasar Penelitian Ilmiah, Bandung: Pustaka Setia, 2005

Sugioyono, Memahami Penelitian Kualitatif, Bandung: Alfabeta,2009

Sugioyono, Metode Penelitian Pendidikan Pendekatan Kunatitatif, Kualitatif, $R$ dan $D$, Bandung: Alfabeta,2010. 